\title{
About Intermedialities: A Review Article of New Work by Paech and Schröter, Chapple and Kattenbelt, and Ellerström
}

\author{
Arno Gimber \\ Complutense University Madrid \\ Asunción López-Varela Azcárate
Complutense University Madrid
}

Follow this and additional works at: https://docs.lib.purdue.edu/clcweb

ర

Part of the Comparative Literature Commons, and the Critical and Cultural Studies Commons

Dedicated to the dissemination of scholarly and professional information, Purdue University Press selects, develops, and distributes quality resources in several key subject areas for which its parent university is famous, including business, technology, health, veterinary medicine, and other selected disciplines in the humanities and sciences.

CLCWeb: Comparative Literature and Culture, the peer-reviewed, full-text, and open-access learned journal in the humanities and social sciences, publishes new scholarship following tenets of the discipline of comparative literature and the field of cultural studies designated as "comparative cultural studies." Publications in the journal are indexed in the Annual Bibliography of English Language and Literature (Chadwyck-Healey), the Arts and Humanities Citation Index (Thomson Reuters ISI), the Humanities Index (Wilson), Humanities International Complete (EBSCO), the International Bibliography of the Modern Language Association of America, and Scopus (Elsevier). The journal is affiliated with the Purdue University Press monograph series of Books in Comparative Cultural Studies. Contact: <clcweb@purdue.edu>

\section{Recommended Citation}

Gimber, Arno; and López-Varela Azcárate, Asunción. "About Intermedialities: A Review Article of New Work by Paech and Schröter, Chapple and Kattenbelt, and Ellerström." CLCWeb: Comparative Literature and Culture 12.3 (2010): <https://doi.org/10.7771/1481-4374.1659>

This text has been double-blind peer reviewed by $2+1$ experts in the field.

The above text, published by Purdue University Press (CPurdue University, has been downloaded 1057 times as of 11/ $07 / 19$.

This document has been made available through Purdue e-Pubs, a service of the Purdue University Libraries. Please contact epubs@purdue.edu for additional information.

This is an Open Access journal. This means that it uses a funding model that does not charge readers or their institutions for access. Readers may freely read, download, copy, distribute, print, search, or link to the full texts of articles. This journal is covered under the CC BY-NC-ND license. 


\section{PURDUE}

UNIVERSITY PRESS <http://www.thepress.purdue.edu>

\section{CLCWeb: Comparative Literature and Culture}

ISSN 1481-4374 <http://docs.lib.purdue.edu/clcweb> Purdue University Press (CPurdue University

CLCWeb: Comparative Literature and Culture, the peer-reviewed, full-text, and open-access learned journal in the humanities and social sciences, publishes new scholarship following tenets of the discipline of comparative literature and the field of cultural studies designated as "comparative cultural studies." In addition to the publication of articles, the journal publishes review articles of scholarly books and publishes research material in its Library Series. Publications in the journal are indexed in the Annual Bibliography of English Language and Literature (Chadwyck-Healey), the Arts and Humanities Citation Index (Thomson Reuters ISI), the Humanities Index (Wilson), Humanities International Complete (EBSCO), the International Bibliography of the Modern Language Association of America, and Scopus (Elsevier). The journal is affiliated with the Purdue University Press monograph series of Books in Comparative Cultural Studies. Contact: <clcweb@purdue.edu>

Volume 12 Issue 3 (September 2010) Book Review Article 15

Arno Gimber and Asunción López-Varela,

About Intermedialities: A Review Article of New Work by Paech and Schröter, Chapple and Kattenbelt, and Ellerström

<http://docs.lib.purdue.edu/clcweb/vol12/iss3/15>

Contents of CLCWeb: Comparative Literature and Culture 12.3 (2010)

<http://docs.lib.purdue.edu/clcweb/vol12/iss3/> 
Arno Gimber and Asunción López-Varela,

"Review Article of New Work by Paech and Schröter, Chapple and Kattenbelt, and Ellerström" page 2 of 8

CLCWeb: Comparative Literature and Culture 12.3 (2010): <http://docs.lib.purdue.edu/clcweb/vol12/iss3/15>

\section{Arno GIMBER and Asunción LÓPEZ-VARELA}

\section{About Intermedialities: Review Article of New Work by Paech and Schröter, Chapple and Kattenbelt, and Ellerström}

Because of the rapid change in electronic media, the tendency to limit the concept of and research on intermediality to the relations between literature and other arts or media such as film only fails to convince. Nowadays, multiple methods, combinations, and approaches exist with regard to the phenomena of interaction between different arts in various media formats. Terms such as intermediality, multimedia, inter-art, comparative arts, the other arts, etc., are in use and interactions are approached from intertextual perspectives, postcolonial hybridism, or from the point of narratological, cognitive, (comparative) cultural, or media studies. Experts from the fields of literary criticism, cultural studies, or media and communication studies feel competent to work on the broad area of intermediality. Therefore, the greatest objection to studies such as those collected Intermedialität analog / digital. Theorien - Methoden - Analysen, edited by Joaquim Paech and Jens Schröter, is that conceptual blurring of the object of research occurs in a poorly defined interdisciplinary context with disparate theoretical proposals and whose results often provide no more than postmodern arbitrariness hardly usable in specific interpretations of the phenomena of intermediality.

Intermediality, associated historically with the exchangeability of expressive means and aesthetic conventions between different art and media forms, is a dominant trend in the arts and the media of the twentieth century owing mostly to the emergence of hypermedia paradigms. We can speak of the fusion of different arts and media into new forms and the representation conventions operating in several media. However, there ought to be no confusion with the representation of one medium in another medium, termed "remediation" by Jay David Bolter and Richard Grusin. With regard to the rise of digital media, Paech and Schröter are aware that intermediality means more than the "crossfertilization of the arts" as formulated by Oskar F. Walzel in his Wechselseitige Erhellung der Künste already in 1917. Intermediality means more than the hybridization of the arts: its ultimate consequence is the possibility of simulation of any form of medial features through digital programming, the reconstruction and almost ad infinitum combination of different media in virtual space. Paech and Schröter have taken this into account and present a comprehensive volume on intermediality. Divided in five sections, the volume includes forty articles with theoretical proposals and intermedial analyses of all kinds (literary, analog media, digital, and performative). Many of these contributions, for example that of Jürgen E. Müller on intermediality the historiography of the media help to differentiate the multiple approaches to the mixing of different arts. Several articles are original because they include discussions on new approaches to intermediality such as, for example, rhythm (Michael Lommel), the body (Irmela Schneider), or synesthesia in general (Stefan Rieger). But above all, focus is on the distinction between analog and digital media and this makes the volume attractive and innovative. The theoretical base of many of the articles is found in an earlier volume Analog / Digital. Opposition oder Kontinuum? Zur Theorie und Geschichte einer Unterscheidung, edited by Alexander Böhnke and Jens Schröter. After theoretical considerations, the first group of studies is with focus on "literary media intermediality." Here again the primacy of literature over other media is still evident and some articles are disappointing, despite of the innovative air. Among the more traditional studies, Jochen Mecke's article is of note as he discusses the film Don Quixote by Orson Wells and argues that hypermediality is already implicit in Cervantes's novel. Not surprisinaly, Mecke emphasizes the technique of mise-enabîme which is useful to describe certain intermedial processes.

Studies in the next section are on painting, photography, and cinematography. Some contributions are exciting precisely because intermedial readings provide new information regarding the aesthetic and artistic development: for example, Paech discusses the concept of blurring and Vittoria Borsò considers medial transgression as an indication of the postmodern paradigm shift towards the arts. Nevertheless, some contributions are film analyses and this is less interesting. Performative media become inter, we learn in the following section, not only when modern dance works with electronic techniques (digital) but also in creating new spaces through gaps and leaps. The role of computer manipulation is to introduce innovations to the art of dance precisely through the merger of space, screen, 
Arno Gimber and Asunción López-Varela,

"Review Article of New Work by Paech and Schröter, Chapple and Kattenbelt, and Ellerström" page 3 of 8

CLCWeb: Comparative Literature and Culture 12.3 (2010): <http://docs.lib.purdue.edu/clcweb/vol12/iss3/15>

and body and through a construction of inter which is not only medial but also local. This conceptualization constitutes the bridge to the last section of the volume, on the intermediality of digital media. Here, the object of the investigation points to a postmodern kind of Gesamtkunstwerk, in this case with regard to interactive games, worlds constructed in a virtuality merging all media. When we enter the field of digital intermediality, where a picture, for example, can be transformed into sound, we have reached the summit of interpretative capacity. Thus, the last articles in the volume touch on the limits of the concept of intermediality: digital simulation challenges the traditional application of the concept of correlation between different art forms. Overall, studies in the volume raise interesting issues and questions of relevance and usefulness such as for example the assumption of high mimesis when intermedial compositions occur or the discovery that visuality can function as tertium comparationis between different expressions of art. Of note is that Sandra Poppe's Visualität in Literatur und Film. Eine medienkomparatistische Untersuchung moderner Erzähltexte und ihrer Verfilmungen (2007) complements issues raised in the volume.

Starting from the postcolonial theory of Homi Bhabha and insisting on the prefix inter one reaches the "third space" in intermedial studies, which marks the meeting point of various expressions in art. Intermediality, according to Paech, is a distinctive form of inter, particularly when it occurs in virtual places. Here we are on a slippery slope, but the remarkable thing is that after media mixing, works of art take on additional values. However, if we accept this final thesis of the volume as argued by various contributors to the volume, unilateral media are always the result of a prior form of intermediality: for example, in the genesis of a poem in order to provide a single idea, musical impressions can be decisive. Understood this way, intermedial analysis is just one type of re-knowing (Wiedererkennen), which, on the other hand, includes the danger that the analyst can get lost in the pre-, hyper-, and archtexts, as was the case years ago in the application of the theory of Barthian intertextuality to literary interpretation. Although the volume provides a wide range of reflections on intermedial theories, certain aspects such as the relationship between literature and architecture are missing. This would be an interesting field, for example, when questioning how architecture and literature interrelate in terms of their aesthetic discourse or how architectural tropes apply to literary texts, or how literary strategies are used in architectural studies. We would also have liked to find more contributions on musical aspects within the swing of relationships among the arts, for music hides great potential among diverse media. But these observations do not constitute serious objections to a volume, a valuable contribution to theorizing about how and in which ways the arts interconnect and intersect, how they come into dialogue. The entry into such newer fields such as transmediality shows that the attempt to find a definitive direction in intermedial studies has not reached its end.

The above matters are evident in Intermediality in Theatre and Performance, edited by Freda Chapple and Chiel Kattenbelt. The volume is a collection of studies about corporeality, performance, and intermediality. Among the contributions is Andy Lavender's article about the immediacy in relation to mise-en-scène and the production of pleasure in contemporary mixed media theatre productions and Ralf Remshardt's article about remediation and acting in silent cinema. Of particular interest is Peter M. Boenisch's theoretical framework where the emphasis on medium as an agency or means of doing something and that underpins the issue of media as cultural artefacts since, as Boenisch notes "media are by no means a neutral means to communicate or express something" (105). Boenisch turns to Walter Benjamin to explain how "the mode of human sense perception changes with humanity's entire mode of existence" for "the manner in which human sense perception is organized, the medium in which it is accomplished, is determined not only by nature but by historical circumstances as well" (105). Boenisch goes on to discuss the seminal work of Bolter and Grusin and their notion of remediation, according to which "a medium is that which remediates. It is that which appropriates the techniques, forms, and social significance of other media and attempts to rival or refashion them in the name of the real" (Bolter and Grusin qtd. in Boenisch 105). Thus, as Boenisch notes "it seems that what is new about the new media is not based on any inherent individuality guaranteeing their difference from old media. Instead, the new media build into the new format some of the existent features of the old; and in doing this they redefine the old media, who continue to survive very well in the updated versions" (107). Boenisch's discussion brings forth the theme of representation establishing a hierarchy between factual and fictional worlds and assuming a mimetic relationship between the actual 
Arno Gimber and Asunción López-Varela,

"Review Article of New Work by Paech and Schröter, Chapple and Kattenbelt, and Ellerström" page 4 of 8

CLCWeb: Comparative Literature and Culture 12.3 (2010): <http://docs.lib.purdue.edu/clcweb/vol12/iss3/15>

thing and its mediatized representation in which the latter appears as "a 'second order reality'" whether as idealist representation of a crude reality in terms of the beautiful and the sublime, as a realist rendering of the actual thing, or as a surreal invention of blatant Science Fiction" (109; on second order observation, see the school of [radical] constructivism). In all cases, he argues, the experience, whether factual or fictional, is felt in the same way because it is authentic, and this "authenticity of any medial world-making includes a significant spatial effect, as 'making worlds' means creating spaces ... some ... quite literal, and others rather metaphorical" (110). He also notes the sensorial layer, the phenomenological experience added to the semiotic reality he terms performance, and which he tries to ground on the medium of theatre in the last part of his discussion. In order to do that he turns to Lev Manovich's notion of "transcoding" as "the translatability of virtually any kind of data, allowing blending various types of audiovisual information, and to store, access, display, exchange, and replicate them by means of a single machine" (Manovich qtd. in Boenisch 110). Boenisch's reading of Manovich links transcoding to Benjamin's notion of technological reproduction and the emphasis on the semiotics of perception and theatrical reproduction beyond original presence. However, Boenisch fails to link this sensorial to any bodily or corporeal experience in a convincing way.

In the same volume, Christopher Balme analyzes analyzes Michel de Certeau's work and Ian Chambers who focus on perception and the role of the observer or "Walkman," as Chambers names it. The main thesis can be summarized in Chambers's words: "In the manifest refusal of sociability the Walkman nevertheless reaffirms participation in a shared environment. It directly partakes in the changes in the horizon of perception that characterize the late twentieth century, and which offers a world fragmenting under the mounting media accumulation of intersecting signs, sounds and images" (Chambers qtd. in Balme 119). In referring to the role of audio theatre, Balme explains that "an important effect of this walkman-induced or directed theatre was the almost complete effacement of the narrative in the traditional diegetic sense" (123). Thus, "the overall effect of audio theatre is to intensify spatial perception in the sense of basic physical orientation" (123). Balme's argument moves one step closer towards an exploration of corporeal implications and his exploration of spatial metonymy contributes to "a destabilization of borders between work and frame, perception and participation" (123). Unfortunately he stops there. Meike Wagner's work in the same volume takes this argument one step further with an exploration of puppet theatre and a new definition of intermediality as "a matrix, which shapes and produces theatrical bodies through a negotiation between the discourse of the body, the spectator and concepts of materiality" (128). She investigates "the intersections of phenomenology and media theory, where theorists working in these fields consider corporeal perception as an interplay between the perceiving and the perceived, and thus introduce the spectator as a corporeally involved perceiver rather than only as a decoding and signifying mind whose position, traditionally, was to interpret a pre-existing message" (128). Wagner refers to Maurice Merleau-Ponty's works, where he develops an "ontology of seeing and flesh, which contradicts hermetic concepts of subjectivity, Ego and presence" (Merleau-Ponty qtd. in Wagner 129), grounding inter-subjectivity in a dialectical between what is seen and unseen (the invisible), the familiar and the non-familiar. This is conceptualization of subjectivity is also constituted by non-symbolic forces (body, acts, feelings, drives) and, owing to its self-reflexive consciousness, capable of strategic self-fashioning and responsible acting. For this reason the subject-agency interferes in existing codes and texts, employing them as scenery for engaging in the symbolic interaction with others and her or his own gaze. The subject thus absorbs foreign texts, utterances, and signifying systems of the past and present but also transforms and revises them. Robin Nelson turns to Pierre Bourdieu's notion of habitus to propose a hypothesis grounded in the changing "disposition whereby viewers engage with the apparatus - to be in some sense present within the medium-while at the same time, being consciously aware of the medium with which they are engaging" (148), coming as close as possible to Bolter's and Grusin's notion of "hypermedium." Nelson grounds the study of the intermediality of screen spaces in cultural studies: "a continuum of increasing depths of immersion, ranging from a temporary suspension of disbelief in traditional television fiction, through a deeper immersion in a role-playing computer game, to a full simulation of an unreal world experienced as if directly through sense-perception but in fact through the wiring of a virtual reality head-set" (148). Following Bryan S. Morse, Nelson claims that "images 
Arno Gimber and Asunción López-Varela,

"Review Article of New Work by Paech and Schröter, Chapple and Kattenbelt, and Ellerström" page 5 of 8

CLCWeb: Comparative Literature and Culture 12.3 (2010): <http://docs.lib.purdue.edu/clcweb/vol12/iss3/15>

have been transformed from static representations of the world into spaces in which events happen that involve and engage people to various degrees in physical space" (Nelson 148).

Language and semiotic theories of the past century have been important in conceptualizing the relation between subject and object, capturing the mutual construction of speaker and cultural system at the point of enunciation without resort to the freedom-determinism binary of ontologies that inscribe subjects and objects. It is in this sense that Chapple's and Kattenbelt's collected volume is of particular value. However, the collection shows the necessity for further research in the question of performance, audience participation and corporeality in intermedial exchanges. Studies in the volume volume point towards the need for a new hermeneutic theory for identity - or, rather, subjectivity in process - negotiated through intermedial exchanges and no longer underscoring the role of agency. Some of this is available in Chapple's 2008 edited collection we refer to above, La intermedialidad / Intermediality.

Studies in Media Borders: Multimodality and Intermediality, a volume edited by Lars Elleström, range from theoretical issues centered on the core question of media borders to case studies such as medieval ballads, biopoetry, lettrism, architecture, field guides, music, film, digital media, performance, etc. The volume opens with Elleström's semiotic framework where he explains how media are related to each other: what they have in common, in which ways they differ, and how these differences are being bridged over by intermediality. The material of this theoretical framework consists of the notions of modality and mode. A secondary aim of the framework is to bring the two fields of research - intermedial and multimodal studies - together. The model presented does not start with the units of established media forms, but with the basic categories of features, qualities, and aspects of all media. Four modalities are defined and related to each other: the material modality, the sensorial modality, the spatiotemporal modality, and the semiotic modality. The four modalities are found on a scale ranging from the tangible to the perceptual. All media can be described as being constituted by varying modes of these modalities. Media that are mainly identified by their modal appearances we can call "basic media." However, there are at least two other aspects involved in media constructions and media definitions. These qualifying aspects complement the modalities. The first of the two qualifying aspects is the origin, delimitation, and use of media in specific historical, cultural, and social circumstances. The second of the two qualifying aspects includes esthetic and communicative characteristics. Art forms and other cultural media types always rely on the two qualifying aspects and can hence be called "qualified media." A technical medium is any object or body that "realizes," "mediates," or "displays" basic and qualified media. According to Elleström, a technical medium can thus be described as "form," while basic and qualified media are "content," and it can be identified according to the range of basic media that has the capacity of mediating.

The media borders that prepare the ground for intermediality are consequently of at least two kinds: media differ partly because of modal dissimilarities and partly because of divergences concerning the qualifying aspects of media. In order to understand, describe, and interpret intermedial relations such as on the one hand combination and integration of media and on the other hand mediation and transformation of media, the intriguing complexity of modal relations and qualifying aspects must be considered properly. All media are, in shifting ways, both fundamentally similar and fundamentally dissimilar and hence intermediality involves many sorts of border crossings that the proposed model can help to relate to each other systematically. Irina Rajewsky explains in her article that the debate about intermediality is characterized by a variety of heterogeneous approaches, spanning a vast range of subject-matter and research perspectives. A host of critical approaches makes use of the concept, each of them with its own premises, methodology, terminology, and delimitations. Equally, the specific objectives pursued by different disciplines in conducting intermedial research vary considerably. However, generally speaking, "intermediality" refers to relations between media, to medial interactions and interferences (see also Rajewsky's Intermedialität). In this sense, intermediality can be said to serve first and foremost as a generic term for all those phenomena that involve more than one medium and thus (as indicated by the prefix inter) in some way take place between media. Accordingly, the crossing of media borders has been defined as a founding category of intermediality. This conception arises from the assumption of tangible borders between individual media, of medial specificities and differences. In fact, any reference to intermediality implicitly presumes that it is indeed possible to 
Arno Gimber and Asunción López-Varela,

"Review Article of New Work by Paech and Schröter, Chapple and Kattenbelt, and Ellerström" page 6 of 8

CLCWeb: Comparative Literature and Culture 12.3 (2010): <http://docs.lib.purdue.edu/clcweb/vol12/iss3/15>

delimit individual media, since we can hardly talk about intermediality unless we can discern and apprehend distinguishable entities between which there could be some kind of interference. Recently, however, it is precisely this fundamental premise of discernible media borders that has been called into question by stressing, explains the Rajewsky, and thus she seeks to specify how media can be conceived as distinct and how they actually come into play in concrete intermedial practices.

What is very interesting about this volume is the fact that many articles fall half-way between theory and application and, rather than just exploring ekphrasis or re-mediation, they go on to focus on the aspects that might enable intermedial dialogue, such as the necessity for complex and nontopographical frameworks for knowledge management, the phenomenological impact and material aspects of sign systems, and the importance of the visual mode. For instance, Axel Englund explores the implications of traditional topographic metaphorical models in the study of relations between music and literature, and explains that they envision medial areas as spatially separate, inviting conceptualization as transported across media borders, while a model allowing simultaneity and dynamic interplay should be sought. Ágnes Pethő makes use of in-between Deleuzian spaces outlined in Paech's article in Intermedialität analog / digital we discuss above and connect these to Michael Godard's art. Pethő outlines and exemplifies four types of ekphrasis: 1) a multiplication of media layers "opening up" towards each other and remediating each other, 2) ekphrasis as a "figure of oblivion," 3) the functioning of ekphrastic metaphors, and 4) the "museum of memory" and the deconstruction of ekphrasis. From a semiotic perspective, Christina Ljungberg concludes in her article that intermedial acts are 1) highly performative, as we are confronted with hybrid forms that generate something new and unique, 2) strongly self-reflexive, since they focus attention both on their own mode of production and on their own semiotic character, which is heightened by the increasing digitalization of interacting media, and they 3) constitute a highly effective communication strategy, as they give readers/viewers/listeners access to different levels of meaning. Her contribution is illustrated with examples of works by performer Laurie Anderson and digital artist Lucia Leao. Hajnal Király explores the relation between writing and observing (spectatorship) as complementary activities, reciprocally conditioning each other in the so-called "writer's movies" of the 1990s, mostly coming from the Far East, and which, according to Király, overturn systematically the strict delimitation between literature and film, the idea of conceptuality of the first and visuality of the latter. Király's article is illustrated through a semiotic analysis of Béla Tarr's Satan's Tango, a seven-and-a-half-hour movie merging both trends mentioned above and going beyond a close textual reading. Valerie Robillard seeks to demonstrate the need to employ ontological systems in the delineation of medial types, systems that have proven indispensable to other disciplines (such as the natural sciences and linguistics) in determining the relative positions of concepts and categories with respect to one another. She proposes a pragmatic intertextual model to delineate and differentiate types of medial interaction, most specifically between verbal and visual texts and uses it to analyze Calum Colvin's multimedial photographs based on James MacPherson's Ossian poems.

The majority of the other articles in the volume offer case studies to the initial theoretical questions. For instance, Sigurd Kværndrup approaches the medieval ballad as an intermedial art form. and Håkan Sandgren explores field guides to birds as examples of intermediality because they combine descriptive prose with images, maps, and transcriptions of bird song. Sami Sjöberg presents French lettrism as intermedial for its blending poetry, narrative fragments, and visual arts and proposes two new concepts for the analysis of intermedial writing: "visual apostrophe" examines transfers between media and locates through the use of invented signs, omissions in the text and "meontologization" shows how information from these invented signs is not enough to supplement signification and it therefore tracks how nothingness connects to these intermedial transfers. Siglind Bruhn offers an example or "transmedialization" and she argues from a visual through a verbal and on to a musical representation. Regina Schober explores Igor Stravinsky's work along the lines of Benjamin's understanding of art's propensity to transcend simultaneously and bring to light its own materiality and substance. Claus Clüver discusses the work of Brazilian poet/art Eduardo Kac who experiments with diverse forms of interactive poetry (videopoetry, holopoetry, and digital poetry). Katalin Sándor analyzes Dubravka Ugrešić's work as an example of a text disrupted into (textual) photographs, albums, museums, archives, cards, collections, and as a work of recollection and memory. The volume ends 
Arno Gimber and Asunción López-Varela,

"Review Article of New Work by Paech and Schröter, Chapple and Kattenbelt, and Ellerström" page 7 of 8

CLCWeb: Comparative Literature and Culture 12.3 (2010): <http://docs.lib.purdue.edu/clcweb/vol12/iss3/15>

with Jürgen E. Müller's exploration of the axe de pertinence of intermediality and his aphorisms on the actual state of affairs of intermedia studies.

In our opinion the above reviewed volumes can be considered representative of recent research on intermediality, multimodality, and remediation. These volumes foreground the need for further research on questions such as performance, interactivity, corporeality, visuality, and agency in intermedial exchanges. We would also like to refer to further volumes which contain valuable work on intermediality relevant to our discussion: Intermediality: The Teachers' Handbook of Critical Media Literacy (1999, edited by Ladislaus Semali and Ann Watts Pailliotet), Gunther Kress's and Theo van Leeuwen's Multimodal Discourse: The Modes and Media of Contemporary Communication (2001), Multimodality in Language and Speech Systems (2002, edited by Björn Granström, David House, and Inger Karlsson), Changing Borders: Contemporary Positions in Intermediality (2007, edited by Jens Arvidson, Mikael Askander, Jørgen Bruhn, and Heidrun Führer), Literary Intermediality: The Transit of Literature through Media Circuits (2007, edited by Maddalena Pennacchia Punzi), Media Encounters and Media Theories (2008, edited by Jürgen E. Müller), La intermedialidad / Intermediality (2008, edited by Freda Chapple), and John A. Bateman's Multimodality and Genre: A Foundation for the Systemic Analysis of Multimodal Documents (2008).

\section{Works Cited}

Arvidson, Jens, Mikael Askander, Jørgen Bruhn, and Heidrun Führer, eds. Changing Borders: Contemporary Positions in Intermediality. Lund: Intermedia Studies P, 2007.

Bateman, John A. Multimodality and Genre: A Foundation for the Systemic Analysis of Multimodal Documents. Basingstoke: Palgrave MacMillan, 2008.

Böhnke, Alexander and Jens Schröter, eds. Analog/Digital. Opposition oder Kontinuum? Zur Theorie und Geschichte einer Unterscheidung. Bielefeld: Transcript, 2004.

Chapple, Freda, and Chiel Kattenbelt, eds. Intermediality in Theatre and Performance. Amsterdam: Rodopi, 2006.

Chapple, Freda, ed. La intermedialidad / Intermediality. Special Issue Cultura, Lenguaje y Representación / Culture, Language and Representation 6 (2008).

Elleström, Lars, ed. Media Borders: Multimodality and Intermediality. Basingstoke: Palgrave-Macmillan 2010.

Granström, Björn, David House, and Inger Karlsson, eds. Multimodality in Language and Speech Systems. Dordrecht: Kluwer, 2002.

Kress, Gunther, and Theo van Leeuwen. Multimodal Discourse: The Modes and Media of Contemporary Communication. London: Hodder Arnold, 2001.

Müller, Jürgen E., ed. Media Encounters and Media Theories. Münster: Nodus, 2008.

Peach, Joachim, and Jens Schröter, eds. Intermedialität: Analog/Digital. München: Fink, 2008.

Pennacchia Punzi, Maddalena, ed. Literary Intermediality: The Transit of Literature through Media Circuits. Bern: Peter Lang, 2007.

Poppe, Sandra. Visualität in Literatur und Film. Eine medienkomparatistische Untersuchung moderner Erzähltexte und ihrer Verfilmungen. Göttingen: Vandenhoeck \& Ruprecht, 2007.

Rajewsky, Irina O. Intermedialität, Tübingen: Francke, 2002.

Semali, Ladislaus, and Ann Watts Pailliotet, eds. Intermediality: The Teachers' Handbook of Critical Media Literacy. Boulder: Westview P, 1999.

Walzel, Oskar F. Wechselseitige Erhellung der Künste. Berlin: Reuther \& Richard, 1917. 
Arno Gimber and Asunción López-Varela,

"Review Article of New Work by Paech and Schröter, Chapple and Kattenbelt, and Ellerström"

page 8 of 8

CLCWeb: Comparative Literature and Culture 12.3 (2010): <http://docs.lib.purdue.edu/clcweb/vol12/iss3/15>

Reviewer's profile: Arno Gimber teaches German literature at Complutense University Madrid. His interests in research include cultural studies, transferences of culture and literature between German and Spain, intermedial relations in music and literature, German literature, and European Romanticism and he has published books and articles in these fields. E-mail: <agimber@filol.ucm.es>

Reviewer's profile: Asunción López-Varela teaches English-language literatures at Complutense University Madrid. Her interests in research include multimodal social semiotics, comparative cultural studies, comparative literature, and the use of hypermedia technologies in education and she has published numerous articles in these fields. Email: <alopezva@filol.ucm.es> 